\title{
Effect of nickel uptake on selected growth parameters of Amaranthus viridis $\mathrm{L}$.
}

\begin{abstract}
Johny Joseph*
Department of Botany, Bharathiar University, Coimbatore-641046 (Tamil Nadu), India Jayaram Reddy

Department of Botany, St. Joseph's Post Graduate Centre, Bengaluru-560027 (Karnataka), India

\section{Sayantan}

Department of Life Sciences, CHRIST (Deemed to be University), Hosur Road, Bengaluru- 560029 (Karnataka), India

${ }^{*}$ Corresponding author. E-mail: johny.joseph@christuniversity.in

Abstract

Nickel is an essential element for normal physiological functions in plants. At higher doses (>50 mg/kg, as per WHO) it is toxic to plants and humans, which can bring about oxidative stress affecting the physiological functions of plants and is also considered carcinogenic to human beings. To manage nickel pollution in environment, proper chemical or phytoremediation techniques are required. In this regard nickel accumulator plants would offer a cost effective and environmental friendly phytoremediation method. In the present study, the nickel phyto-accumulation potential of Amaranthus viridis from soil was evaluated to check the tolerance level and the impact on selected morphological parameters like total biomass, plant height, root length and number of leaves. Nickel uptake by $A$. viridis was studied from $\mathrm{Ni}$ contaminated soil amended with $20,40,60,80 \mathrm{mg} / \mathrm{Kg}$ of Ni exposure under controlled conditions. Toxic effects and tolerance of the plant to toxic doses of nickel was evaluated by correlating the uptake per gram of biomass with various parameters of plant like its height, biomass, root length and, number of leaves. Supply dependent maximum nickel uptake of $108 \mu \mathrm{g} / \mathrm{gm}$ and corresponding decrease in growth parameters were recorded up to $60 \mathrm{mg} / \mathrm{Kg}$ exposure. This study indicates the uptake of nickel by $A$. viridis increases with increase in supply up to $60 \mathrm{mg} / \mathrm{kg}$ and beyond $60 \mathrm{mg} / \mathrm{kg}$, the uptake decreases. The study also shows uptake of nickel per gram of biomass has a significant negative correlation mainly with parameters like plant height $(R=-0.71$ at 0.05 level of significance) and total biomass ( $R=-0.83$ at 0.05 level of significance) where as other parameters like length of root and number of leavers are not significantly affected $(P>0.05)$ with uptake of nickel per gram of biomass.
\end{abstract}

\section{INTRODUCTION}

Solid waste generation rate is alarmingly increasing at the global level with a figure of 1.3 billion tons/year and per capita generation of $1.2 \mathrm{~kg} /$ day. With rapid growth of population and urbanization, this number is expected to reach 2.2 billion tons/ year by 2025 (World Bank Report 2018). As reported by Kumar et al. (2017), approximately 133760 tons of municipal solid wastes (MSW) are being generated in India per day, with per capita value of approximately 0.17 and $0.62 \mathrm{~kg} /$ day in small towns and cities, respectively. The city of Bengaluru that spreads over 800 Sq. Km with close to 10 million population, generates around 5000 tonnes of MSW per day, with per capita generation of $0.5 \mathrm{~kg} /$ day (Navin and Sivapullaih 2016).Disposal of this waste is one of the globally important problems, related to urban develop-

\section{Article Info}

DOI:10.31018/jans.v10i3.1838

Received: July 25, 2018

Revised: August 17, 2018

Accepted: August 20, 2018

How to Cite

Joseph, J. et al. (2018). Effect of nickel uptake on selected growth parameters of Amaranthus viridis L. Journal of Applied and Natural Science, 10(3): $1011-1017$ ments with severe but different impacts at the local level; wastes dumps are one of them. Unscientific management of MSW in Bengaluru has resulted in proliferation of several open dump sites (Chanakya et al. 2011; Ramachandra et al., 2018), which could lead to land pollution by heavy metals.

Heavy metals are the elements that have a high density $(5 \mathrm{~g} / \mathrm{cm})$. Heavy metal contamination has dire consequences and it affects agricultural yield, soil fertility and soil microorganisms. Although, traces of heavy metals are present naturally in the soil due to weathering of parental materials, they are not toxic to the environment. But due to the disturbances of the geochemical cycle of metals by man, heavy metals may accumulate in the soil beyond its defined levels causing risk to the ecosystem (Sayantan and Shardendu, 2017). 
Phil-Eze (2010) reported about the hazardous impact on plant life due to the open waste dumping. However, there are certain plants, like Nepeta hindostana, Achyranthes aspera, Cassia occidentalis, Amaranthus spinosus, Lantana camara, and Prosopis julifloraare found to be common in the dump sites as they become acclimatized to their adverse effects (Tripathi and Misra 2012). The adaptation achieved by these plants may be due to natural causes(Astarraei and Ariabod 2008) that make further them suitable to tolerate and remediate heavy metals present, by the phenomenon, known as phytoremediation (Nagendran et al. 2006).

Phytoremediation is considered as one of the best emerging technologies to remediate metal contaminated soils because of its cost effectiveness, extensive applicability and aesthetically pleasing techniques that require smaller disposal facilities (loana-Alinaet al., 2006). Moreover, such treatment causes less environmental disturbance and the remediated soil can be used for agricultural practices (Salt et al. 1995). In the past, various plant species have been used (Kamran et al. 2014) to study the reclamation of contaminated soil with the help of phytoremediation technique. Using local plants for phytoremediation is more useful because these plants can grow and adapt in local physiological conditions when compared to other plants (Kamran et al. 2014). Among all different methods of phytoremediation, phytoextraction is the most widely used and accepted method to remediate the soil where the plant roots take up the heavy metals from the soil and translocate it to the aerial parts of the plant (McGrath et al. 2001). The resulted plant can be harvested and thereby, heavy metals are removed from the site. This method is more effective only in hyper accumulators that accumulate large concentration of metal/metalloids with reasonable biomass production (da Silva et al., 2018).

Though there are many studies of hyper accumulator plants that can accumulate large amount of metal in its cells, no deep investigation has been carried out in plants that accumulate metals in smaller quantities and its tolerance capacity .In the present study one such plant species Amaranthus is chosen as it was found common in the open dumpsites of Bangalore There are only a few studies regarding the tolerance mechanisms to metals in the Amaranthus species as reported in the literature (Mellem et al. 2009; Zhang et al.,2010; Shevyakova et al., 2011).

Nickel, which is selected for this study, is a heavy metal used extensively in the manufacture of batteries and also a major metal component in the manufacturing of coins. Nickel is also used as additive for imparting green colour to the glass thereby making it also a coloring agent. Though it serves as a micronutrient to the plants when pre- sent in soil in minimum concentration, it makes the soil contaminated when present beyond a certain level $(50 \mathrm{mg} / \mathrm{kg}$, as per WHO),further leading to nickel toxicity in plants (Bhaleraoet al. 2015). Nickel produced by anthropogenic sources are readily uptaken by the plants than that from naturally occurring species. The excess of $\mathrm{Ni}$ accumulation in plant tissues not only results in physiological stress, such as chlorosis, necrosis, decrease in water potential and transpiration, inhibition of growth etc., but also the oxidative stress (Seregin and Kozhevnikova 2006; Bhalerao et al. 2015). The ability to take up nickel differ among plants and depends on their tolerance level (Valentina et al. 2013). Most common plants identified for the tolerance of nickel include cauliflower, turnip and some plants belonging to Leguminosae family (Seregin and Kozhevnikova 2006)

Present study, is carried out to understand the toxic effects and tolerance of Amaranthus plant to toxic doses of nickel by correlating the uptake per gram of biomass with various parameters of plant like its height, biomass, root length and, number of leaves. Amaranthus virdis is used as an alternative for Amaranthus spinosa which was found growing extensively in the open dumpsites of Bangalore. The unavailability of seeds of Amaranthus spinosa as it is a wild species was the reason for choosing Amaranthus virdis. Different concentrations of nickel used in this study are 20, 40, 60 and $80 \mathrm{mg} / \mathrm{Kg}$ soil to check the tolerance level of Amaranthus plant.

\section{MATERIALS AND METHODS}

Preparation of mother culture for Amaranthus viridis: Two to three seeds of Amaranthus viridis were sown in each coco peat filled with soil. The trays were kept at a suitable place in the green house where it was exposed to $70-80 \%$ of sunlight. The trays were watered daily. After 3-4 days the seeds germinated into small plantlets.

Preparation of metal solution and contaminated soil: Nickel solutions $(20 \mathrm{mg} / \mathrm{ml})$ was prepared by dissolving $5.27 \mathrm{~g}$ of nickel sulphate in distilled water and made up to $100 \mathrm{ml}$. The uncontaminated soil was broken into small pieces and sieved to get a fine texture of the soil without any lump and stones. $4 \mathrm{ml} / 8 \mathrm{ml} / 12 \mathrm{ml} / 16 \mathrm{ml}$ of the Nickel solution $(20 \mathrm{mg} / \mathrm{ml})$ were mixed with $4 \mathrm{~kg}$ of soil to make the soil with the concentrations of $20 \mathrm{mg} /$ $\mathrm{Kg} / 40 \mathrm{mg} / \mathrm{Kg} / 60 \mathrm{mg} / \mathrm{Kg} / 80 \mathrm{mg} / \mathrm{Kg}$ Nickel respectively.

Experimental set up: The metal solution was allowed to settle in each pot for a day. Then 11 days old plant seedlings were taken from the mother culture and planted in the pots with 4 plants in each pot. The plants were watered with Hoagland solution at an interval of every 3-4 days and the morphological characteristics such as height of the plant and number of leaves were 
recorded at frequent intervals of 15 days to confirm the growth of the plant.

Plant sampling: Amaranthus viridis was harvested from each pot after two months of metal exposure. Roots were initially washed under gently running tap water to remove loosely adhered sand particles followed by rinsing with $3 \% \mathrm{HCl}(3 \mathrm{ml} \mathrm{HCl}$ in $100 \mathrm{ml}$ of Distilled water $)$ for leaching out of minerals adsorbed on the surface of roots. The shoots and acid rinsed roots were washed at least three times with distilled water (Sayantan and Shardendu 2013). The plant growth parameters were recorded such as plant height (in $\mathrm{cm}$ ), root length (in $\mathrm{cm}$ ) and number of leaves per plant. After harvesting, samples of leaves, stem and roots were oven dried at $100^{\circ} \mathrm{C}$ for three to four days and dry weights were measured everyday till the achievement of constant weight. For analysis of nickel content in plant parts, dried root, dried leaf and dried stem samples were grinded using mortar and pestle. Dry weight (DW) biomass (in g) of each plant was determined using electronic balance. As per Walinga et al. 1995, the ground and weighed samples were transferred into different conical flasks. $5 \mathrm{ml}$ of concentrated $\mathrm{HNO}_{3}$ and few $\mathrm{ml}$ of $\mathrm{H}_{2} \mathrm{O}_{2}$ were added and evaporated to incipient dryness. When it was completely dried, the residue was dissolved in $10 \mathrm{ml}$ of $3 \%$ $\mathrm{HNO}_{3}$. Concentration of $\mathrm{Ni}$ in the solution prepared from plant residues was determined by inductively coupled plasma atomic emission spectrometry (ICP-AES; JY HROOBA 2000 France). Wavelength selected for analysis was $221.647 \mathrm{~nm}$. Statistical analysis: All statistical analyses were performed using Microsoft Excel Office Version 13. Student $T$ test was carried out to analyse the significance in variation of mean response of control and treatments.

\section{RESULTS}

The metal accumulation potential of Amaranthus viridis from the soil amended with nickel concentration of 20,40,60 and a maximum of $80 \mathrm{mg} /$ Kgwas studied in relation to the plant biomass, plant height, root length and number of leaves. Concentration of 20,40,60 and a maximum of $80 \mathrm{mg} / \mathrm{Kg}$ nickel was selected based on survival ofAmaranthus viridisin different concentrations from our preliminary experiments.

Effect of nickel supply on uptake: Dose dependent increase in nickel uptake was observed in Amaranthus viridis plants grown in soil sup-

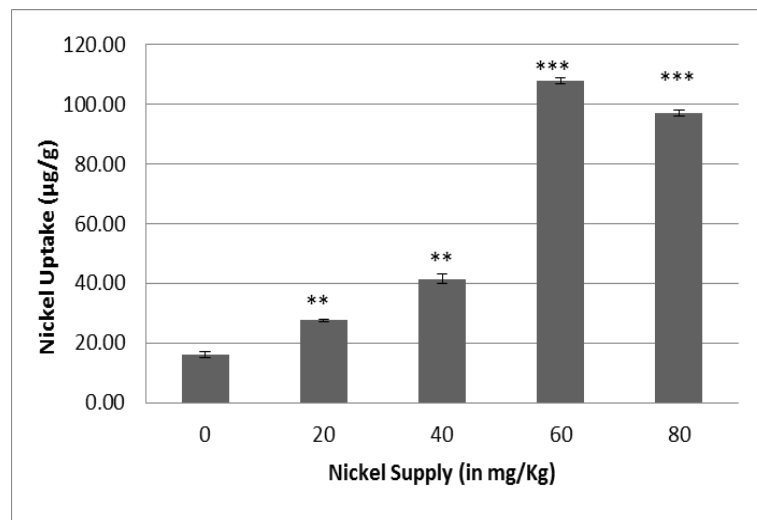

Fig. 1. Nickel supply as a function of nickel uptake in Amaranthusviridis. $\left({ }^{*}\right),\left({ }^{* *}\right),\left({ }^{* * *}\right)$ indicates the mean difference of nickel uptake in treated soil is significant when compared to control soil at $P<0.05, P<0.01$ and $P<0.001$ respectively.

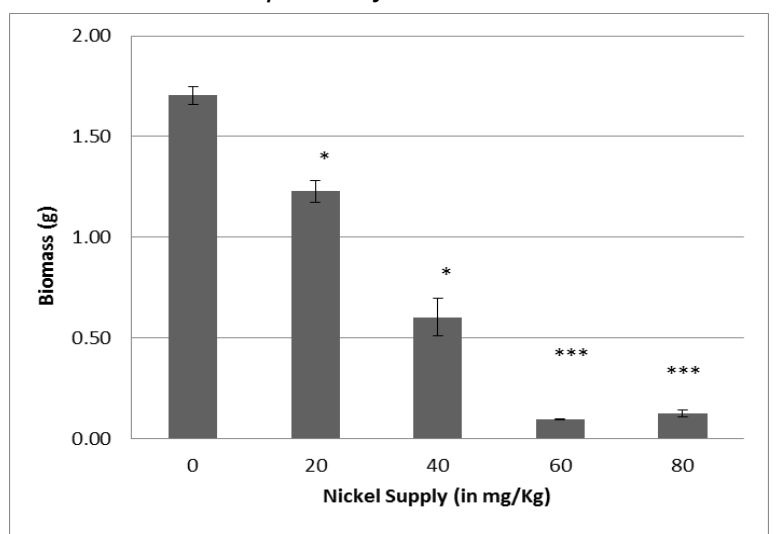

Fig. 2. Nickel supply as a function of Biomass in Amaranthusviridis. $\left({ }^{*}\right),\left({ }^{* *}\right),\left({ }^{* * *}\right)$ indicates the mean difference of biomass of nickel treated soil is significant when compared to control soil at $P<0.05, P<$ 0.01 and $P<0.001$ respectively

plied with nickel up to $60 \mathrm{mg} / \mathrm{Kg}$ of nickel but slightly reduced at the supply of $80 \mathrm{mg} / \mathrm{Kg}$ (Fig. 1). Nickel uptake at $16 \pm 1.14 \mu \mathrm{g} / \mathrm{g}$, was observed in the plant grown in control and maximum accumulation of $108 \pm 1.41 \mu \mathrm{g} / \mathrm{g}$ was observed in the plant grown at supply of $60 \mathrm{mg} / \mathrm{Kg}$ nickel. Nickel uptake as compared with control soil was statistically highly significant at soil amended with 60 and 80 $\mathrm{mg} / \mathrm{Kg}(P<0.001)$ while at less than $60 \mathrm{mg} / \mathrm{Kg}$ amendment, nickel uptake was significant at $1 \%$ $(P<0.01)$. At highest nickel supply of $80 p p m$, nickel accumulation capacity of Amaranthus viridis was reduced to $97 \pm 1.41 \mu \mathrm{g} / \mathrm{g}$.

Effect of nickel supply on biomass: The biomass of Amaranthus viridis decreased with the increase in nickel supply up to $60 \mathrm{mg} / \mathrm{Kg}$ of nickel

Table 1. The experimental design for nickel uptake by Amaranthus viridis plant.

\begin{tabular}{llllll}
\hline \multicolumn{5}{c}{ Layover of pots for Nickel } \\
\hline Harvested on & control & $20 \mathrm{mg} / \mathrm{Kg}$ & $40 \mathrm{mg} / \mathrm{Kg}$ & $60 \mathrm{mg} / \mathrm{Kg}$ & $80 \mathrm{mg} / \mathrm{Kg}$ \\
\hline \multirow{2}{*}{2 ndmonth } & Soil & $20 \mathrm{ppm} \mathrm{Ni}+$ soil & $40 \mathrm{ppm} \mathrm{Ni}+$ soil & $60 \mathrm{ppm} \mathrm{Ni}+$ soil & $80 \mathrm{ppm} \mathrm{Ni}+$ soil \\
& (4plants) & $(4 \mathrm{plants})$ & (4plants) & (4 plants) & (4 plants) \\
\hline \hline
\end{tabular}




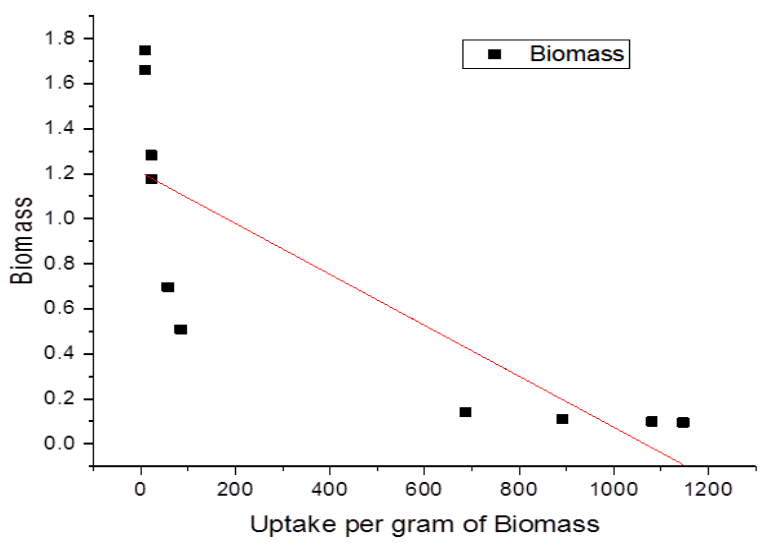

Fig. 3. Co-relation of nickel uptake per gram biomass with total biomass (in grams) of Amaranthus viridis, $R$

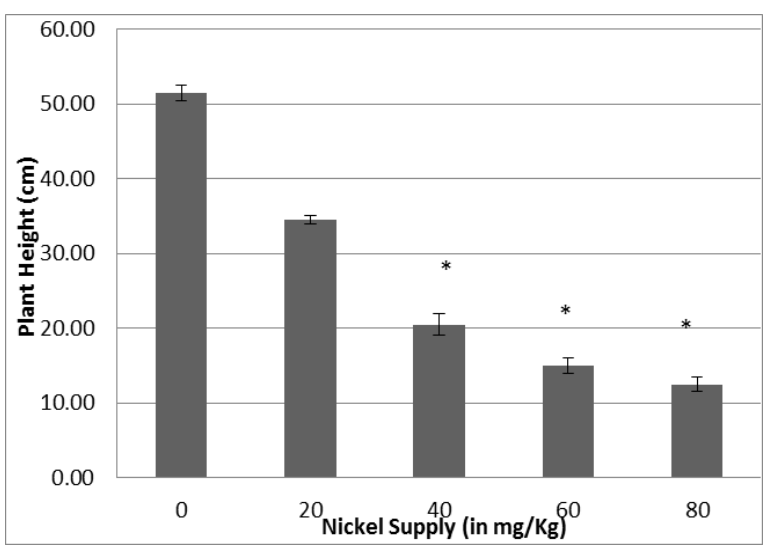

Fig. 4. Nickel supply as a function of plant height in Amaranthus viridis. $\left({ }^{*}\right),\left({ }^{* *}\right),\left({ }^{* * *}\right)$ indicates the mean difference of plant height of plants grown in nickel treated soil is significant when compared to control soil at $P<0.05, P<0.01$ and $P<0.001$ respectively

in a dose dependent manner; but at the highest nickel supply of $80 \mathrm{mg} / \mathrm{Kg}$ there was a marginal increase in biomass as compared with nickel supply of $60 \mathrm{mg} / \mathrm{Kg}$. (Fig.2). Biomass, as assessed by the dry weight, of $1.705 \mathrm{~g}$ was observed in the plant grown in control and decreased maximum at supply of $60 \mathrm{mg} / \mathrm{Kg}$ nickel with a biomass of $0.09 \mathrm{~g}$. Compared to $60 \mathrm{mg} / \mathrm{Kg}$ nickel supply, at $80 \mathrm{mg} / \mathrm{Kg}$ proportionate decrease in nickel uptake per gram biomass was observed $(1114.09 \pm 47.07 \mu \mathrm{g} / \mathrm{g}$ versus $788.31 \pm 145 \mu \mathrm{g} /$ g;Fig.6) which led to lesser toxic effects on the plant thereby enhancement of total biomass. Biomass as compared with control soil was statistically highly significant at nickel amendment of soil at 60 and $80 \mathrm{mg} / \mathrm{Kg}(\mathrm{P}<0.001)$, while at lower $(20$ and $40 \mathrm{mg} / \mathrm{Kg}$ ) amendment biomass was significant at $5 \%(P<0.05)$. Total biomass of the plant showed significant negative correlation with nickel uptake per gram of biomass $(R=-0.83, P<0.01$; Fig. 3).

Effect of nickel supply on plant height: Amaranthus viridis height showed an inverse relationship with nickel supply. Compared to

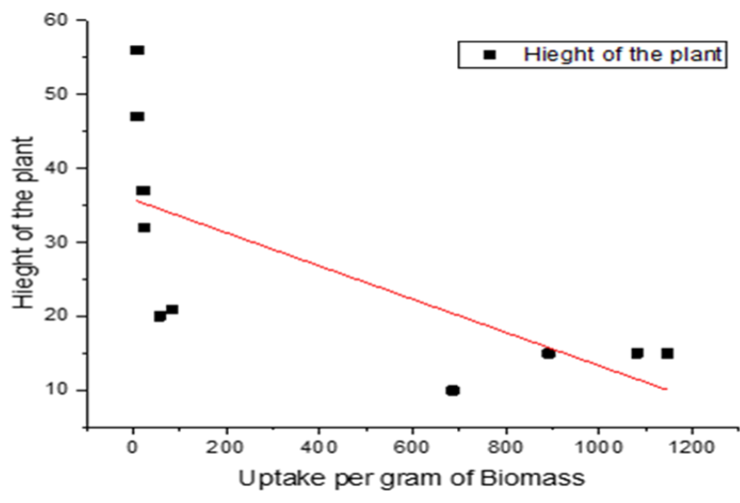

Fig.5. Co-relation of nickel uptake per gram biomass with Height of Amaranthus viridis, $R=-0.71, p<0.05$.

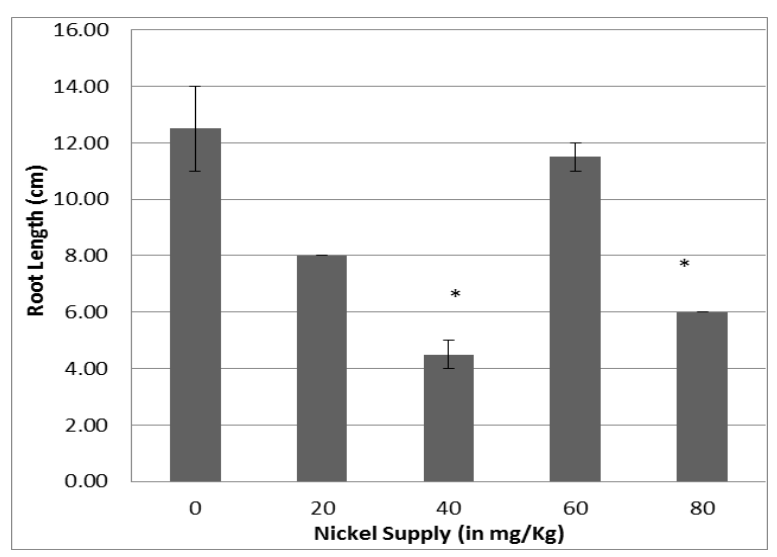

Fig. 6. Nickel supply as a function of Root Length in Amaranthus viridis. $\left({ }^{*}\right),\left({ }^{* *}\right),\left({ }^{* * *}\right)$ indicates the mean difference of root length of plants grown in nickel treated soil is significant when compared to control soil at $P<0.05, P<0.01$ and $P<0.001$ respectively

$54.5 \pm 6.3 \mathrm{~cm}$ observed in plant grown in control soil dose dependent decrease in plant height up to $12.5 .5 \pm 3.5 \mathrm{~cm}$ was observed in soil amended with $80 \mathrm{mg} / \mathrm{Kg}$ nickel (Fig. 4).Plant height as compared with control soil was significant at nickel amendment of soil at $40 \mathrm{mg} / \mathrm{Kg}$ and above at $5 \%$ $(P<0.05)$ while not significant at less than $40 \mathrm{mg} /$ $\mathrm{Kg}$ amendment. Plant height negatively correlated with Nickel uptake per gram of biomass ( $R=$ 0.71, $\mathrm{P}<0.05$; Fig. 5).

Effect of nickel supply on root length: Root length of Amaranthus viridis decreased with nickel supply up to $40 \mathrm{mg} / \mathrm{Kg}$ exposure (Fig.6). In control plants root length of $12.5 \pm 2.12 \mathrm{~cm}$ was recorded and at $40 \mathrm{mg} / \mathrm{Kg}$ nickel exposure drastic reduction in root length at $4.5 \pm 3.5 \mathrm{~cm}$ was recorded. Root length as compared with control soil was statistically significant at $5 \%(\mathrm{P}<0.05)$ in nickel amendment of soil at 40 and $80 \mathrm{mg} / \mathrm{Kg}(P<0.05)$ while at less than 20 and $60 \mathrm{mg} / \mathrm{Kg}$ amendment was not significant. Nickel exposure at $60 \mathrm{mg} / \mathrm{Kg}$ caused the root length to increase to $11.5 \pm 0.07 \mathrm{~cm}$, however with further increase in nickel at $80 \mathrm{ppm}$ stunted the root length to $6 \mathrm{~cm}$. 


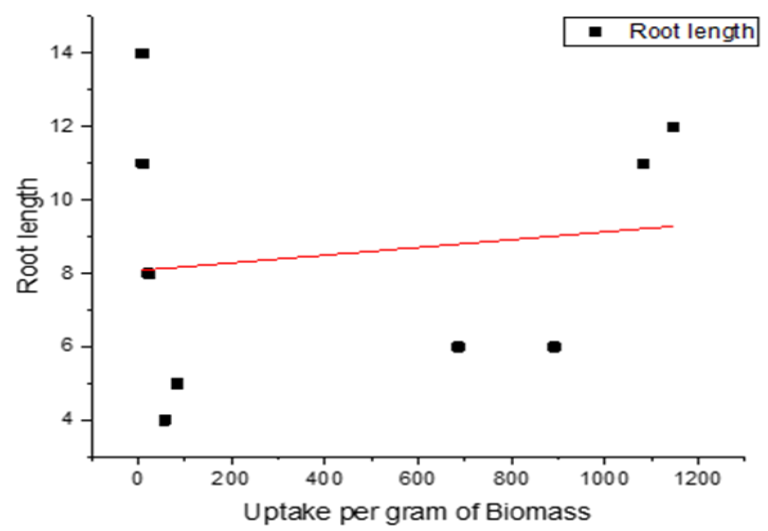

Fig. 7. Co-relation of nickel uptake per gram biomass with root length in Amaranthus viridis, $R=0.15$, $P>0.66$.

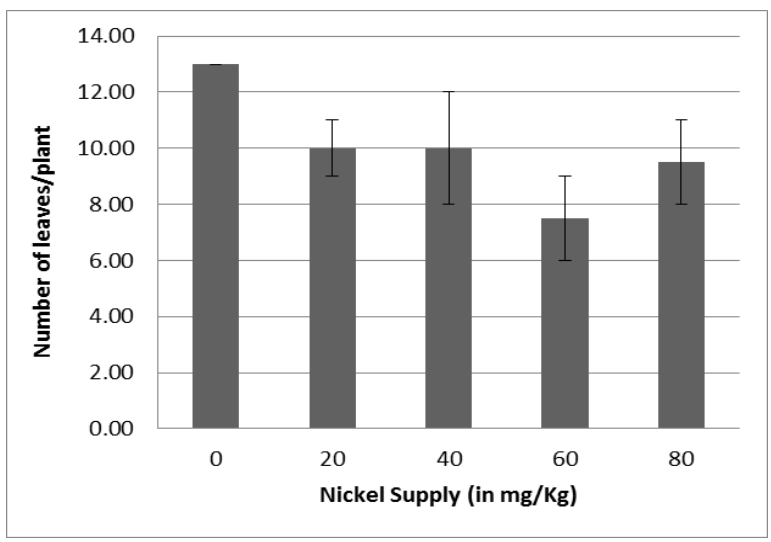

Fig. 8. Nickel supply as a function of Number of leaves in Amaranthus viridis.

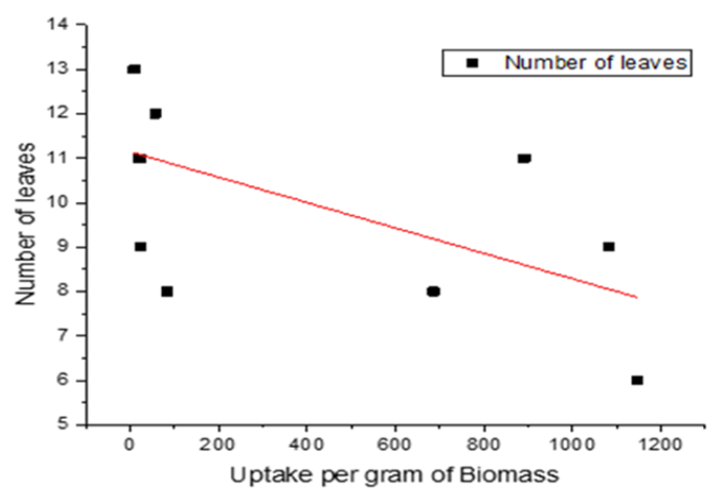

Fig. 9. Co-relation of nickel uptake per gram biomass with number of leaves in Amaranthus viridis, $R=-0.59, P>0.05$.

No correlation of root length with either nickel uptake or nickel uptake per gram of biomass was observed (Fig, 7).

Effect of nickel supply on number of leaves: Nickel exposure decreased the number of leaves in Amaranthus viridis in a dose dependent manner up to $60 \mathrm{mg} / \mathrm{Kg}$ (Fig.8). Plants grown in con- trol soil showed 13 leaves per plant, which decreased maximum to $7.5 \pm 2.12$ leaves per plant in soil amended with $60 \mathrm{mg} / \mathrm{Kg}$ nickel. At highest nickel supply of $80 \mathrm{mg} / \mathrm{Kg}$ there was as marginal increase in number of leaves per plant at $9.5 \pm 2.12$ as compared with treatment of $60 \mathrm{mg} / \mathrm{Kg}$ nickel. However, the variation in number of leaves observed in different treatment were not statistically significant. Number of leaves correlated negatively with nickel uptake $(R=-0.59$, Fig. 9) but was not significant.

\section{DISCUSSION}

The effect of toxic doses of nickel on the tolerance of $A$. viridis was studied by comparing $\mathrm{Ni}$ uptake per gram biomass with the various plant parameters like height, biomass, root length and number of leaves. The toxic dosages of $\mathrm{Ni}$ included $20 \mathrm{mg} /$ $\mathrm{Kg}, 40 \mathrm{mg} / \mathrm{Kg}, 60 \mathrm{mg} / \mathrm{Kg}$ and $80 \mathrm{mg} / \mathrm{Kg}$. Nickel uptake in in the plant as compared with control soil increased with increase in concentration up to $60 \mathrm{mg} / \mathrm{kg}$ with a marginal reduction of uptake in the highest nickel supply $80 \mathrm{mg} / \mathrm{Kg}$.Nickel supply at $60 \mathrm{mg} / \mathrm{Kg}$ increased the uptake of nickel by 2 to $>5$-fold increase compared to lower amendment or control soil. With further increase in nickel supply there was decrease in its uptake, indicating the threshold concentration for the plant to withstand the toxicity of Nickel. Fabrizio and coworkers (2013) have observed Nickel tolerance up to $50 \mu \mathrm{M}$ levels of $\mathrm{NiCl}_{2}$ without affecting the physiological functions in A.paniculatus cultivated in hydroponics culture. This finding indicates the variation in different species of Amaranthus in their ability to withstand nickel toxicity and uptake nickel. Further analysis of physiological parameters should provide more valuable information about the underlying mechanism of tolerance to Nickel toxicity and uptake. Total biomass of the plant showed significant negative correlation $(R=$ $0.83, P<0.01$ ) with nickel uptake per gram of biomass, further confirming its toxic effect, although being a nutrient element.Plant species are known to tolerate up to $10 \mathrm{mg} / \mathrm{Kg}$ of nickel and elevated nickel concentration alters the plant physiology due to oxidative stress, inhibition of photosynthesis, alteration in the mineral uptake leading to growth inhibition (Nieminen et al. 2007). In the present study progressive reduction in biomass was recorded in A.viridis at more than $10 \mathrm{mg} / \mathrm{Kg}$ exposure. Similarly, Valentina et al. (2013) reported dose dependent decrease in stem, root and leaf biomass in Amaranthus species with nickel exposure up to $150 \mu \mathrm{M}$ grown in hydroponics culture. With regard to plant height though there was negative correlation with nickel uptake per gram of biomass in all levels of stress ( $R=-$ $0.707, \mathrm{P}<0.05$ ) it was not significant in less than $40 \mathrm{mg} / \mathrm{kg}$ treatment plants. Valentina et al. (2013) reported heavy metal exposure dependent varia- 
tion in the sensitivity of root and shoot in Amaranthus plants exposed to Nickel.Roots were more sensitive at $25 \mu \mathrm{M}$ concentration while the stem showed higher tolerance to higher concentration of $100 \mu \mathrm{M}$. Assuncao et al. (2003) reported higher sensitivity of shoots compared to root in Thlaspicaerulescens exposed to toxic concentration of Nickel. Thus, plant and different organs differ in their ability to tolerate and exhibit variation in their response to heavy metal toxicity. In the present study length of the shoot was progressively reduced with increasing concentration of nickel, while root length showed proportionate decrease in root length up to $60 \mathrm{mg} / \mathrm{Kg}$ exposure and increased thereafter at $60 \mathrm{mg} / \mathrm{Kg}$ exposure with a further decrease at $80 \mathrm{mg} / \mathrm{kg}$ exposure. Galardi et al. (2007) reported higher sensitivity of roots to nickel toxicity when compared to shoot in Alyssum bertolonii. In the present study as the nickel uptake in shoot and root was not quantified separately differential toxic effects of heavy metal could not be analyzed further. Number of leaves correlated negatively with nickel uptake $(R=-0.59$, Fig. 9) but was not significant. Similarly, Valentina et al. (2013) reported no significant difference in leaf mass whereas significant reduction in leaf surface area at exposure of more than $50 \mu \mathrm{M}$ Nickel concentration.

Heavy metal tolerance is well documented in plants and in this regard, systematic controlled studies of plants exposed to toxic concentration of heavy metals provide valuable insights for their potential phytoremediation. Ziarati and Alaedini (2014) evaluated the potential of Amaranthus plant to uptake $\mathrm{Ni}$ in soil supplied with $5-10 \mathrm{mmol} /$ $\mathrm{L}$ of Nickel in presence of dried tea leaves and found up to $7.23 \%$ Nickel uptake in a $30-50$ day growing period. Shevyakova et al. (2011) evaluated three hybrids of Amaranthus plants for Nickel uptake and found up to $4 \mathrm{mg} \mathrm{Ni}$ uptake/gm dry weight of plant when exposed to nickel concentration up to $250 \mu \mathrm{M}$. Chunilallet al. (2005) studied the nickel uptake by two Amaranthus species in soil amended with $20-100 \mathrm{mg} / \mathrm{Kg}$ nickel and found a maximum $18.58 \mu \mathrm{g} / \mathrm{g}$ nickel uptake in root in 10 weeks of growth. In the present study, $A$. highest Nickel uptake of $108 \pm 1.44 \mu \mathrm{g} / \mathrm{g}$ at $60 \mathrm{mg} / \mathrm{Kg}$ nickel supply with a negative correlation between all parameters studied and increase in uptake of nickel. This can be attributed to the activities of antioxidant enzymes which decreases with increase in concentration of the metal.As a result, plant failed to cope up with metal stress and increases the oxidative stress (Tauqeer et al. 2016).

\section{Conclusion}

It is a very well-known fact that the heavy metals (like $\mathrm{Ni}$ ) pose toxicity to the biological organisms at the morphological as well as physiological lev- els. The present study also reported the similar thought. The increase in the dosage of nickel supplies resulted in the increase in nickel uptake (up to $108 \mu \mathrm{g} / \mathrm{g}$ dry weight biomass) by $A$. viridis, thus subsequently decreasing the biomass (up to 0.09 g) of the plant along with decrease in plant height (up to $12.5 \mathrm{~cm}$ ), root length (up to $4.5 \mathrm{~cm}$ ) as well as decrement in the number of leaves (up to 7.5). Hence, in conclusion to this study, it can be suggested that various plant parameters can serve as markers to assess the heavy metal remediation behaviour of plants.

\section{REFERENCES}

1. Assunção, A. G. L., Bookum, W. M., Nelissen, H. J. M., Voojis, R., Schaat, H. and Ernst, W. H. O. (2003). Differential metal-specific tolerance and accumulation patternsamong Thlaspicaerulescenspopulations originating from different soil types. New Phytologist, 159: 411-419.

2. Astarraei, A. R. andAriabod, S.(2008). Effect of municipal solid waste leachate on plant growth and micro elements uptake of green chilli. Environmental Sciences, 5: 95-106.

3. Bhalerao, S. A., Sharma, A. S., and Poojari, A. C. (2015). Toxicity of nickel in plants. International Journal of Pure \& Applied Bioscience, 3: 345-355.

4. Chanakya, H.N.,Shwetmala, K., and Ramachandra, T.V. (2011). Estimating unauthorized dumping of USW around cities - a case study of Bangalore. $2^{\text {nd }}$ International Conference on Sustainable Waste Management (ICON-SWM), Kolkata, India, pp. 636-642.

5. Chunilall, V., Kindness,A. and Jonnalagadda,S. B. (2005). Heavy Metal Uptake by Two Edible Amaranthus herbs Grown on Soils Contaminated with Lead, Mercury, Cadmium,and Nickel. Journal of Environmental Science and Health, Part B Pesticides, Food Contaminants, and Agricultural Wastes, 40: 375-384

6. da Silva, E.B., de Oliveira, L.M., Wilkie, A.C., Liu, Y., and Ma, L.Q. (2018). Arsenic removal from Ashyperaccumulator P. vittata biomass: Coupling extraction with precipitation. Chemosphere, 193:288294.

7. Fabrizio, P., Valentina, I., Alexandra, C., Nina, I. S., Nataliya R., Vladimir, V. K. and Massimo Z, (2014). Evaluation of nickel tolerance in Amaranthus paniculatusL.plants by measuring Photosynthesis, oxidative status, anti-oxidative response and metal-binding molecule content. Environmental Science and Pollution Research, 22: 482-494

8. Galardi, F., Corrale, I., Mengoni, A., Pucci, S., Barletti, L., Barzanti, R., Arnetoli,M., Gabbrielli, R., and Gonnell,C. (2007). Intraspecific differences in nickel tolerance and accumulation in the Ni-hyper accumulators Alyssum bertolonii.Environmental and Experimental Botany, 60: 377-384.

9. Tauqeer, H.M.,Ali, S., Rizwan, M., Ali, Q.,Usman R.S., Saeed, R., Iftikhar, U., Ahmad, R., Farid, M., and Abbasi, G.H.(2016). Phytoremediation of heavy metals by Alternanthera bettzickiana: Growth and physiological response. Ecotoxicology and Environmental Safety, 126: 138-146.

10.loana-Alina, C., Nicoleta, N., and Narcis, P.G. (2016). Monitoring the best available techniques im- 
plementation at the ash and slug landfill Utvin, Timis Country, Romania. Procedia Engineering, 161: 21002103.

11.Kamran,M.A., and Aqeel, M. (2014).The potential of the flora from different regions of Pakistan in phytoremediation a review. Environmental Science and Pollution Research, 21: 801-812.

12.Kumar, S., Smith, S.R., Fowler, G., Velis, C., Kumar, S. J., Arya, S., Kumar, R.R., and Cheeseman, C. (2017). Challenges and opportunities associated with waste management in India. Royal Society Open Science, 5: 160764

13.Mellem, J.J., Baijnath, H., and Odhav, B.(2009). Translocation and accumulation of $\mathrm{Cr}, \mathrm{Hg}, \mathrm{As}, \mathrm{Pb}$, $\mathrm{Cu}$ and $\mathrm{Ni}$ by Amaranthus dubius (Amaranthaceae) from contaminated sites. Environmental Science Health, 44:568-575

14.McGrath, S.P., Zhao, F.J., and Lombi, E.(2001). Plant and rhizosphere process involved in phytoremediation of metal-contaminated soils. Plant and Soil, 232: 207-214

15.Nagendran, R., Selvam, A., Joseph,K., andChiemchaisri, C. (2006). Phytoremediation and rehabilitation of municipal solid waste landfills and dumpsites- A brief review. Waste Management, 26: 1357-1369

16.Naveen, B. P., and Sivapullaiah, P. V. (2016). Solid waste management in Bengaluru - current scenario and future challenges. Innovation Energy and Research, 5: 139

17.Nieminen, T. M., Ukonmaanaho, L., Rausch, N., andShotyk, W.(2007). Biogeochemistry of nickel and its release into the environment. Metal lons in Life Sciences, 2: 1-30.

18.Phil-Eze, P. O. (2010). Variability of soil properties related to vegetation cover in a tropical rainforest landscape. Journal of Geography and Regional planning, 3: 177-184.

19.Ramachandra, T.V., Bharath, H.A., Kulkarni, G., and Han, S.S. (2018). Municipal solid waste: Generation, composition and GHG emissions Bangalore, India. Renewable and Sustainable Energy Reviewes, 82: 1122-1136.

20.Salt DE, Blaylock M, Kumar NP, Dushenkov. V, Ensley BD andRaskin, 1998. Phytoremediation: A novel strategy for the removal of toxic metals from the environment using plants, Bio/Technology, 13:468-474

21.Sayantan, D., and Shardendu.(2013). Amendment in phosphorus levels moderate the chromium toxicity in Raphanus sativus L. as assayed by antioxidant enzymes activities. Ecotoxicology and Environmental Toxicity, 95: 161-170.

22.Sayantan, D., and Shardendu. (2017). Phosphate amendments moderate the arsenate accumulation and its subsequent oxidative and physiological toxicities in Amaranthus viridisL. Proceedings of the $\mathrm{Na}$ tional Academy of Sciences, India Section B: Biological Sciences, 87: 1343-1353.

23.Shevyakova, N.I., CheremisinaA.I., andKuznetsov, V. (2011).Phytoremediation potential of Amaranthus hybrids: Antagonism between nickel and iron and chelating role of Polyamines. Russian Journal of Plant Physiology, 58: 634-642.

24.Seregin, I.V., and Kozhevnikova, A.D.(2006). Physiological role of nickel and its toxic effects on higher plants. Russian Journal of Plant Physiology, 53:28530.

25.Tripathi, A., and Misra, D.R. (2012). Floral distributions at municipal waste dumpsites in relation to their soil properties: identification of adaptive plants. Bulletin of Environmental and Scientific Research, 1: 1-10.

26.Valentina, I., Fabrizio,P., Alexandra, C., Nina, I.S., Nataliya, R., Valdimir, V.K., and Massimo, Z.(2013). Growth Responses, Metal Accumulation and Phyto removal Capability in Amaranthus plants exposed to Nickel under Hydroponics. Water Air and Soil Pollution, 224:1450.

27.Walinga, I., van Der Lee, J.J., Houba, V.J.G., Vark, W., and Novozamsky, I. (1995). PlantAnalysis Manual. Kulwer Academic Publisher, Dordrecht, the Netherlands.

28.Zhang, B.Y., Zheng, J.S., and Sharp, R.G. (2010). Phytoremediation in engineered wetland: mechanisms and applications. Procedia Environmental Sciences, 2: 1315-1325.

29.Ziarati, P., and Alaedini, S. (2014). The phytoremediation technique for cleaning up contaminated soil by Amaranthus sp. Journal of Environmental and Analytical Toxicology, 4: 1-4. 